\title{
Essential Elements and Their Relations to Phenolic Compounds in Infusions of Medicinal Plants Acquired from Different European Regions
}

\author{
P. Konieczynski ${ }^{1}$ - A. Arceusz ${ }^{1}$ - M. Wesolowski ${ }^{1}$
}

Received: 13 June 2015 / Accepted: 14 August 2015 / Published online: 27 August 2015

(C) The Author(s) 2015. This article is published with open access at Springerlink.com

\begin{abstract}
The aim of this research was to compare chemical composition of herbs acquired from different European countries. The concentrations of $\mathrm{P}, \mathrm{Fe}, \mathrm{Mn}, \mathrm{Zn}, \mathrm{Cu}$, phenolic compounds, and the antioxidant activity were determined in infusions of 27 medicinal herbs ( 7 species) from Lithuania, Serbia, Italy, and Portugal. Total and extractable $\mathrm{P}$ were expressed in milligrams per liter and metals in micrograms per liter and followed the sequence: $\mathrm{Fe}>\mathrm{Mn}>\mathrm{Zn}>\mathrm{Cu}$, while antioxidant activity ranged from 29.4 to $217.8 \mathrm{mg}$ of Trolox equivalent (TE) per liter. Total flavonoids were in the range of 20.5$95.1 \mathrm{mg} \mathrm{L}^{-1}$. The rank order of phenolic compounds assayed by HPLC method (in $\mathrm{mg} \mathrm{L}^{-1}$ of infusion) was as follows: rutin $>$ myricetin $>$ quercetin $>$ kaempferol, and chlorogenic $>$ ferulic $>p$-coumaric $>$ caffeic $>$ gallic acids. Significant correlations were found between total $\mathrm{P}$-inorganic phosphate $\mathrm{P}$, $\mathrm{Zn}-\mathrm{Mn}, \mathrm{Mn}-\mathrm{Cu}$, total flavonoids-antioxidant activity, and quercetin with caffeic and ferulic acids. Generally, medicinal plant infusions differed in their chemical composition, strongly depending on plant species, regardless of the origin from distant geographical areas of Europe. Principal component analysis selected the concentrations of $\mathrm{Cu}, \mathrm{Mn}$, total and inorganic phosphate $\mathrm{P}$, as factors which strongly influence differentiation of the samples. Moreover, infusions from Hyperici herba and Helichrysi inflorescentia contained significant amounts of water-extractable $\mathrm{Mn}$ and $\mathrm{Fe}$ forms as claimed by the Dietary Reference Intakes for humans.
\end{abstract}

P. Konieczynski

pawelkon@gumed.edu.pl

1 Department of Analytical Chemistry, Medical University of Gdansk, Gen. J. Hallera 107, 80-416 Gdansk, Poland
Keywords Essential elements · Phenolic compounds · Antioxidant activity $\cdot$ Medicinal herbs $\cdot$ Statistical methods

\section{Introduction}

Herbal medicinal products are still in focus of researchers worldwide and the consumption of herbal preparations, even in highly developed countries, is high [1-3]. In this situation, there is a necessity to monitor chemical composition of herbal preparations. Moreover, by studying the chemical composition of infusions (infusa), decoctions (decocta), macerates (macerata), herbal teas (plantae ad ptisanam), and herbal tea mixtures (species ad ptisanam), it would be possible to learn which chemical forms of the elements are bioavailable for humans, when using these herbal preparations.

So far, numerous secondary metabolites in herbal medicinal products have been thoroughly studied, including their fingerprint analysis [4-6]. In recent years, the need for standardization of herbal preparations is growing $[7,8]$. Therefore elemental composition of herbal drugs representing different plant species, as well as various morphological plant organs, was investigated [9-11]. Several studies were performed to establish the influence of environment and/or botanical plant species on the chemical composition, including the levels of metallic and non-metallic elements in herbal medicinal products [12-15].

Phenolic compounds were also studied in various herbal medicinal products, including different types of herbal substances, and in herbal preparations [16-21]. For example, the content of phenolic compounds and the antioxidant activity of herbal infusions from Amazonian region were investigated [16]. It was demonstrated that the studied nine herbs had the polyphenol/flavonoid content and antioxidant properties similar to those of a typical infusion obtained from Camellia 
species. A study on a popular antioxidant herb-Cistus incanus has shown that incorrect choice of brewing process parameters can result in decreased polyphenolics content in infusion of that herb [17]. A research on mate tea has revealed that also the way of preparation of herbal infusion has an essential influence on the level of phenolic compounds in the infusion [19].

Several European countries have become important suppliers of herbs used in the pharmaceutical and cosmetics industries. Among them are herbal enterprises located in Southern Europe, for example in Serbia, Bulgaria, Italy, and Portugal, and in the Central and Eastern Europe, including Poland, Ukraine, and Lithuania. Therefore, in this research, a particular emphasis has been laid on chemical composition of herbs originating from distant areas of Europe.

It is commonly known that medicinal plants grow or are cultivated in different climatic conditions, also on various types of soil, climate, and pollution of the environment, so all these factors have a significant impact on plant's chemical composition represented by typical secondary metabolites, such as flavonoids, phenolic acids and also by essential elements. Therefore, the purpose of this study was to compare the chemical composition of medicinal plants representing seven plant species originating from various areas of Europe (Lithuania, Serbia, Italy, and Portugal), including selected essential elements and phenolic compounds. This comparison should help to answer the question whether or not plants of the same species differ significantly taking into account their origin from various European regions. Therefore, analysis of variance, correlation analysis, and multivariate statistical tools, such as cluster and principal component analyses, were applied. Moreover, the contribution of water-extractable forms of $\mathrm{Fe}, \mathrm{Zn}, \mathrm{Mn}$, and $\mathrm{Cu}$ in infusions of the medicinal herbs to the recommended Dietary Reference Intakes were calculated to indicate the most valuable sources of essential elements.

\section{Materials and Methods}

\section{Plant Material and Sample Preparation}

The analyzed herbal medicinal products originated from herbal companies located in Lithuania, Serbia, Portugal, and Italy, as presented in Table 1. The dried plant materials were ground using a Knifetec 1095 sample mill, sieved through a $0.5-\mathrm{mm}$ mesh sieve. (Foss-Tecator, Denmark), and stored in polyethylene containers until analysis.

Infusions of medicinal herbs were obtained by pouring boiling redistilled water $(100 \mathrm{~mL})$ onto $2.0 \mathrm{~g}$ of a plant material. After $15 \mathrm{~min}$, the infusions were filtered through paper filters (Filtrak No 389, Germany) and diluted to $100 \mathrm{~mL}$ with redistilled water obtained from a Heraeus (Switzerland) distillation system.

Next, the infusions were filtered through a $0.20-\mu \mathrm{m}$ nylon membrane filter (Witko Łódź, Poland) into a HPLC vial, as recommended by a procedure for ultracleaning of solvents prior to HPLC analysis. For each sample, the complete assay procedure was repeated in triplicate, and the standard deviation was calculated.

\section{Reagents}

Standards of phenolic acids such as gallic (GA), chlorogenic (CGA), caffeic (CA), $p$-coumaric ( $p \mathrm{CA}$ ), ferulic (FA) and of flavonoids such as rutin (RUT), myricetin $(\mathrm{M})$, quercetin $(\mathrm{Q})$, and kaempferol $(\mathrm{K})$ were purchased from ChromaDex (CA, USA). HPLC-grade methanol was purchased from Avantor Performance Materials Poland S.A., and trifluoroacetic acid (TFA) was from Sigma-Aldrich (St. Louis, MO, USA).

\section{Chromatographic Conditions}

Chromatographic analyses were performed using a HPLC LaChrom (Merck, Darmstadt, Germany) system consisting of an L-7100 pomp, an L-7360 column compartment, and an L-7420 UV/vis detector. The chromatographic separation was performed on a Hypersil Gold C18 column $(250 \times 4.6 \mathrm{~mm}$, i.d. $5 \mu \mathrm{m})$ which was placed in a thermostat at $35{ }^{\circ} \mathrm{C}$. The mobile phase was consisted of solvent $\mathrm{A}$ $(0.05 \%$ TFA in methanol) and solvent B $(0.05 \%$ TFA in water). The optimized gradient elution was performed using the following program: $5-25 \% \mathrm{~A}(0-30 \mathrm{~min}), 25-40 \% \mathrm{~A}$ (30-40 min), 40-60\% A (40-50 min), and 5\% A (50$60 \mathrm{~min}$ ). Conditions for sample pretreatment had previously been optimized by studying the type of solvent (methanol, ethanol), solvent concentration in water, and extraction time [4]. Before starting gradient runs, initial conditions were maintained during $10 \mathrm{~min}$ for column equilibration. The flow rate was set at $1.0 \mathrm{~mL} \mathrm{~min}^{-1}$ and the injection volume was $20 \mu \mathrm{L}$. The wavelength of the UV/vis detector was set at $280 \mathrm{~nm}$ for gallic and $p$-coumaric acids; at $320 \mathrm{~nm}$ for caffeic, ferulic, and chlorogenic acids; and at $370 \mathrm{~nm}$ for flavonoids. The identification of the phenolic compounds in the samples was based on comparison of retention time with those of the standards.

\section{Spectrophotometric Measurement}

For all spectrophotometric measurements, a Metertek SP-870 (South Korea) UV/vis instrument was used. The contents of total flavonoids were directly determined in infusions at $510 \mathrm{~nm}$ using the reaction with $\mathrm{AlCl}_{3}$ based on the rutin standard (Across Organics, Belgium). Total and extractable phosphorus was determined by spectrophotometric method using a phosphate-molybdate complex $(\lambda=650 \mathrm{~nm})$. 
Table 1 The medicinal plant materials under study

\begin{tabular}{|c|c|c|c|c|c|}
\hline Sample no. & Herbal remedy & Medical use & Plant species, botanical family & Herbal company & Country of origin \\
\hline 1 & \multirow[t]{5}{*}{ Equiseti herba } & \multirow{5}{*}{$\begin{array}{l}\text { Diuretic, supporting in } \\
\text { therapy of tuberculosis }\end{array}$} & \multirow{5}{*}{$\begin{array}{l}\text { Equisetum arvense } \\
\text { L., Equisetaceae }\end{array}$} & Dr. P. Karvelis & Lithuania \\
\hline 2 & & & & Adonis Sanobanja & Serbia \\
\hline 3 & & & & Beli gor Svrlijig & Serbia \\
\hline 4 & & & & Ervital & Portugal \\
\hline 5 & & & & Roma & Italy \\
\hline 6 & \multirow[t]{2}{*}{ Polygoni herba } & \multirow{2}{*}{$\begin{array}{l}\text { Hepatoprotective, in therapy } \\
\text { of tuberculosis, diuretic }\end{array}$} & \multirow{2}{*}{$\begin{array}{l}\text { Polygonum aviculare } \\
\text { L., Polygonaceae }\end{array}$} & SVF & Lithuania \\
\hline 7 & & & & Adonis Sanobanja & Serbia \\
\hline 8 & \multirow[t]{5}{*}{ Hyperici herba } & \multirow{5}{*}{$\begin{array}{l}\text { Antidepressant, for pelvic pain } \\
\text { and cramping, anti-inflammatory } \\
\text { for strains, sprains, and contusions }\end{array}$} & \multirow{5}{*}{$\begin{array}{l}\text { Hypericum perforatum } \\
\text { L., Guttiferae }\end{array}$} & SVF & Lithuania \\
\hline 9 & & & & Adonis Sanobanja & Serbia \\
\hline 10 & & & & Moc bilja & Serbia \\
\hline 11 & & & & Planinska & Serbia \\
\hline 12 & & & & Ervital & Portugal \\
\hline 13 & \multirow[t]{3}{*}{ Crataegi folium et flos } & \multirow{3}{*}{$\begin{array}{l}\text { Cardiacum, vasodilatans, } \\
\text { anti-arhythmic }\end{array}$} & \multirow{3}{*}{$\begin{array}{l}\text { Crataegus oxyacantha } \\
\text { L., Rosaceae }\end{array}$} & Acorus & Lithuania \\
\hline 14 & & & & Adonis Sanobanja & Serbia \\
\hline 15 & & & & Roma & Italy \\
\hline 16 & \multirow[t]{5}{*}{ Sambuci flos } & \multirow{5}{*}{$\begin{array}{l}\text { Mild diuretic, increases } \\
\text { sweatening }\end{array}$} & \multirow{5}{*}{$\begin{array}{l}\text { Sambucus nigra } \\
\quad \text { L., Caprifoliaceae }\end{array}$} & Sirdazole & Lithuania \\
\hline 17 & & & & Adonis Sanobanja & Serbia \\
\hline 18 & & & & Beli gor Svrlijig & Serbia \\
\hline 19 & & & & Ervital & Portugal \\
\hline 20 & & & & Roma & Italy \\
\hline 21 & \multirow[t]{5}{*}{ Chamomillae flos } & \multirow{5}{*}{$\begin{array}{l}\text { Anti-inflammatory, immunomodulary } \\
\text { anti-diabetic, acaricidal, } \\
\text { anti-hyperglycemic, anti-microbial }\end{array}$} & \multirow{5}{*}{$\begin{array}{l}\text { Matricaria chamomilla } \\
\text { L., Compositae }\end{array}$} & SVF & Lithuania \\
\hline 22 & & & & Moc bilja & Serbia \\
\hline 23 & & & & Adonis Sanobanja & Serbia \\
\hline 24 & & & & Ervital & Portugal \\
\hline 25 & & & & Roma & Italy \\
\hline 26 & \multirow[t]{2}{*}{ Helichrysi inflorescentia } & \multirow{2}{*}{$\begin{array}{l}\text { Cholereticum, cholagogum, } \\
\text { antihelminticum, antibioticum }\end{array}$} & \multirow{2}{*}{$\begin{array}{l}\text { Helichrysum arenarium } \\
\text { L. Moench, Compositae }\end{array}$} & Ervital & Portugal \\
\hline 27 & & & & Dr. P. Karvelis & Lithuania \\
\hline
\end{tabular}

\section{Radical Scavenging Activity (DPPH Assay)}

A spectrophotometric analysis of radical scavenging activity using the DPPH method with a Trolox calibration curve was performed. This assay is based on the ability of the antioxidant to scavenge the radical cation DPPH. Ten microliters of the infusion were added to $2 \mathrm{~mL}$ of methanolic DPPH $\left(0.04 \mathrm{mmol} \mathrm{L}^{-1}\right)$. After $60 \mathrm{~min}$ of incubation in a dark place at room temperature, the absorbance was measured at $517 \mathrm{~nm}$ using 10-mm quartz cuvettes. A calibration curve in the range $0.1-1.0 \mathrm{mmol} \mathrm{L}^{-1}$ was used for the Trolox, and the data were expressed as a Trolox equivalent antioxidant capacity (TEAC, $\mathrm{mg} \mathrm{L}^{-1}$ ).

\section{Metallic Elements Determination}

The essential metallic elements were assayed using standard analytical conditions (air/acetylene), applying a flame program of the Atomic Absorption Spectrometer 250 Plus
(Varian, Australia) and the following analytical wavelengths (nm): $248.3(\mathrm{Fe}), 213.9(\mathrm{Zn}), 279.5(\mathrm{Mn})$, and $324.8(\mathrm{Cu})$.

\section{Validation of the Analytical Methods}

The validation of the methods included calculation of values of regression equations for calibration curves with $S_{\mathrm{a}}$ and $S_{\mathrm{b}}$, limits of detection (LOD) and quantification (LOQ), as shown in Table 2. By assuming the " $r$ " values higher than 0.99 , the linearity obtained for the assayed elements and other analytes, as well as for the LOD and LOQ values, they were recognized as being on an acceptable level.

As for HPLC determinations, the linearity was examined with standard solutions. Mixed stock solutions $\left(1 \mathrm{mg} \mathrm{mL}^{-1}\right)$ of nine phenolic compounds were prepared. Each calibration curve was based on five different concentrations of a phenolic compound. Calibration working standards were freshly prepared in methanol by appropriate dilution of the stock solutions. The linearity for each phenolic compound was established by plotting the peak area $(Y)$ against concentration 
Table 2 Validation parameters of the developed analytical procedures for quantification of essential elements and phenolic compounds

\begin{tabular}{|c|c|c|c|c|c|c|c|}
\hline \multirow[t]{2}{*}{ Analyte } & \multirow[t]{2}{*}{ Range $\left(\mu \mathrm{g} \mathrm{mL} \mathrm{L}^{-1}\right)$} & \multirow[t]{2}{*}{ Regression equation } & \multicolumn{5}{|c|}{ Parameter of validation } \\
\hline & & & $S_{\mathrm{a}}$ & $S_{\mathrm{b}}$ & Linearity $(r)$ & $\operatorname{LOD}\left(\mu \mathrm{g} \mathrm{mL} L^{-1}\right)$ & LOQ $\left(\mu \mathrm{g} \mathrm{mL} L^{-1}\right)$ \\
\hline $\mathrm{P}$ & $1.6-8.0$ & $A=0.01670+0.10819 \times x$ & 0.0019 & 0.0102 & 0.9988 & 0.05 & 0.15 \\
\hline $\mathrm{Fe}$ & $1.0-5.0$ & $A=0.0014+0.03620 \times x$ & 0.0009 & 0.0030 & 0.9991 & 0.05 & 0.16 \\
\hline $\mathrm{Zn}$ & $1.0-4.0$ & $A=0.09750+0.14730 \times x$ & 0.0147 & 0.0400 & 0.9901 & 0.01 & 0.04 \\
\hline $\mathrm{Mn}$ & $1.0-5.0$ & $A=0.02250+0.10670 \times x$ & 0.0050 & 0.0169 & 0.9965 & 0.02 & 0.05 \\
\hline $\mathrm{Cu}$ & $0.2-1.2$ & $A=-0.0073+0.08980 \times x$ & 0.0040 & 0.0030 & 0.9965 & 0.02 & 0.06 \\
\hline Rutin & $100-500$ & $Y=64,500+11,760 \times x$ & 1421 & 65,104 & 0.9857 & 27.26 & 82.61 \\
\hline Myricetin & $100-500$ & $Y=-2,750,000+41,770 \times x$ & 1468 & 410,277 & 0.9987 & 21.42 & 64.93 \\
\hline Quercetin & $100-500$ & $Y=-2,720,000+44,402 \times x$ & 1501 & 419,604 & 0.9988 & 19.80 & 60.00 \\
\hline Kaempferol & $100-500$ & $Y=-8,020,000+138,100 \times x$ & 5941 & $1,660,545$ & 0.9981 & 22.27 & 67.48 \\
\hline Gallic acid & $10-100$ & $Y=3045 x+40,643$ & 129 & 7835 & 0.9946 & 0.34 & 1.11 \\
\hline Chlorogenic acid & $10-100$ & $Y=16759 x+45,609$ & 474 & 28,777 & 0.9976 & 1.32 & 4.02 \\
\hline$p$-Coumaric acid & $10-100$ & $Y=11974 x+256,233$ & 354 & 21,456 & 0.9974 & 1.40 & 4.89 \\
\hline Caffeic acid & $10-100$ & $Y=1329 x+50,758$ & 91 & 6432 & 0.9953 & 0.76 & 2.95 \\
\hline Ferulic acid & $10-100$ & $Y=6771 x+67,313$ & 359 & 21,780 & 0.9916 & 0.95 & 1.96 \\
\hline
\end{tabular}

$S_{a}$ standard deviation of the slope, $S_{b}$ standard deviation of the intercept, $L O D$ limit of detection, $L O Q$ limit of quantification

$(X)$ of each compound and had been verified by a correlation study. In this way, calibration curves of nine phenolic compounds were obtained. The LODs and LOQs expressed by 3and 10-fold signal-to-noise $(\mathrm{S} / \mathrm{N})$ ratios were also obtained.

\section{Data Analysis}

Statistical analyses such as one-way analysis of variance (ANOVA) and the correlation, cluster (CA), and principal component analyses (PCA) were calculated using a Statistica 7.1 (Statsoft, Poland) software [22]. ANOVA helped to determine statistically significant differences between the analyzed samples due to their origin from different botanical species and from distant areas of growth in Europe. Correlation analysis was used in order to reveal the interrelations among the essential elements and phenolic compounds, whereas multivariate statistical methods helped to find the patterns, in which the studied samples were clustered, and in the case of PCA, this method enabled to reduce the multidimensionality of the experimental database.

\section{Results and Discussion}

\section{The Contents of Macro- and Trace Elements}

The highest level of all studied elements represented total phosphorus—-96.3 $\mathrm{mg} \mathrm{L}^{-1}$. However, in particular samples, its level was differentiated, ranging from 36.7 in Equiseti herba to $184.7 \mathrm{mg} \mathrm{L}^{-1}$ in Sambuci flos. Taking into consideration the mean concentration of total $\mathrm{P}$ in different plant species, the highest amounts of this essential element was found in S. flos and in Chamomillae flos, 146.8 and $124.2 \mathrm{mg} \mathrm{L}^{-1}$, respectively. The lowest level was determined in the species of Helichrysi flos- $56.4 \mathrm{mg} \mathrm{L}^{-1}$. The levels of water-extractable $\mathrm{P}$ in the infusions were about $50 \%$ lower than those of the total P and ranged from 17.1 in E. herba to $87.9 \mathrm{mg} \mathrm{L}^{-1}$ in $S$. flos.

In the group of metallic elements, the highest mean concentration of Fe was found in infusion $-6373.6 \mu \mathrm{g} \mathrm{L}^{-1}$. Next, $\mathrm{Mn}$ can be listed, with the mean of $2102.7 \mu \mathrm{g} \mathrm{L}{ }^{-1}$. The mean concentration of $\mathrm{Zn}$ was found as $966.4 \mu \mathrm{g} \mathrm{L}^{-1}$, and the lowest of $\mathrm{Cu}-75.8 \mu \mathrm{g} \mathrm{L}{ }^{-1}$.

The range of $\mathrm{Fe}$ in the studied samples was from 1703.3 in E. herba to $15,848.2 \mu \mathrm{g} \mathrm{L}^{-1}$ in C. flos. For Mn, the range of concentrations was found from 191.7 in E. herba to $4862.3 \mu \mathrm{g} \mathrm{L}^{-1}$ in Hyperici herba. The amount of $\mathrm{Zn}$ was determined within the range from 272.7 in E. herba to $1622.3 \mu \mathrm{g} \mathrm{L}^{-1}$ in Helichrysi inflorescentia, and the range of $\mathrm{Cu}$ from 28.3 in Polygoni herba to $261.0 \mu \mathrm{g} \mathrm{L}^{-1}$ in E. herba. These values are similar to those reported earlier for medicinal plants [9-15].

\section{Total Contents of Phenolic Compounds and the Antioxidant Activity}

All results are presented in Table 3. The mean concentration of total flavonoids in infusions was established as $54.7 \mathrm{mg} \mathrm{L}^{-1}$ with the standard deviation of $1.9 \mathrm{mg} \mathrm{L}^{-1}$. The lowest level was determined in $P$. herba-20.5 $\mathrm{mg} \mathrm{L}^{-1}$, whereas the highest in $H$. herba-95.1 $\mathrm{mg} \mathrm{L}^{-1}$. High total flavonoid content was also found in other samples of Hyperici herba, from 


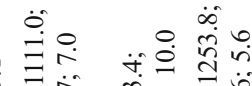

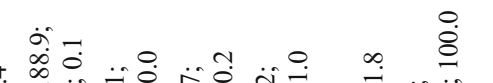

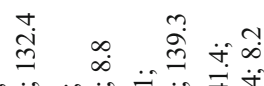

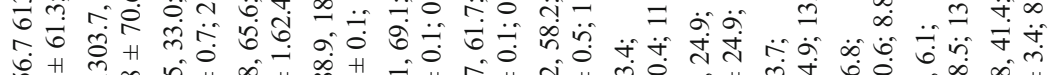

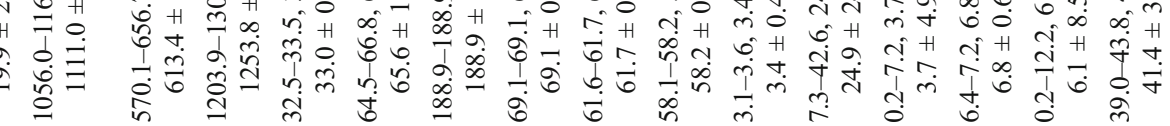

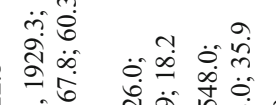

象

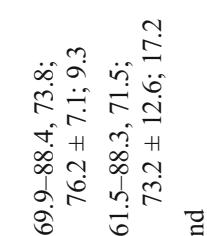

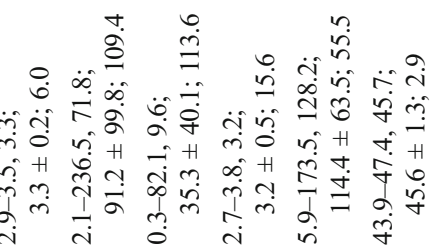

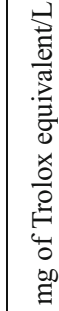

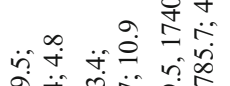

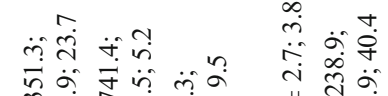

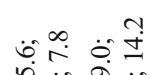

I.

ले ठ্র

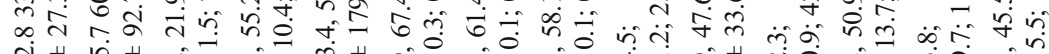

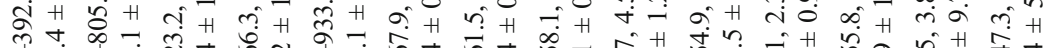

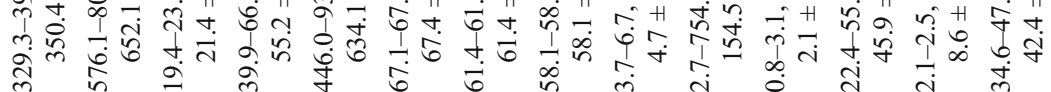

ปิن寸

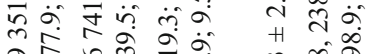

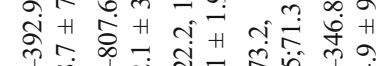

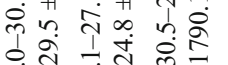

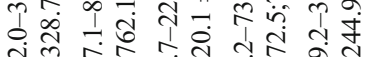

क्ते

तु

$\exists \quad \exists$

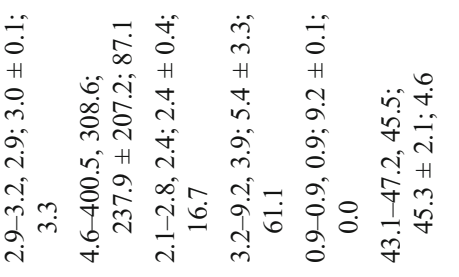

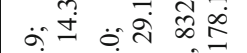

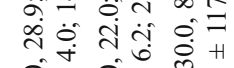

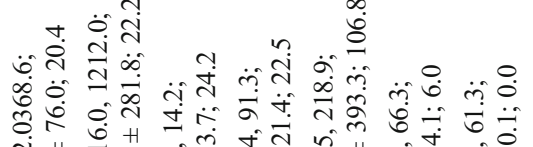

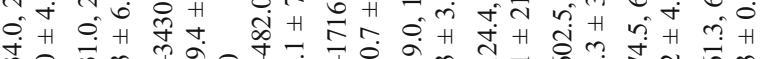

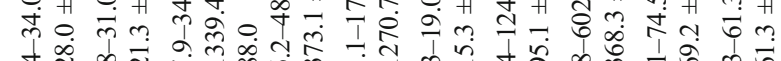

กิ่

$\infty$

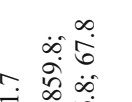

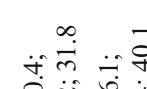

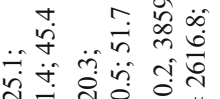

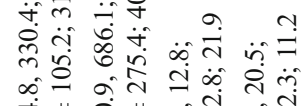

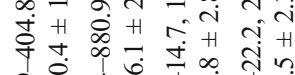

$\therefore+10$ in

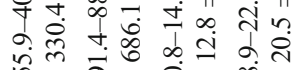

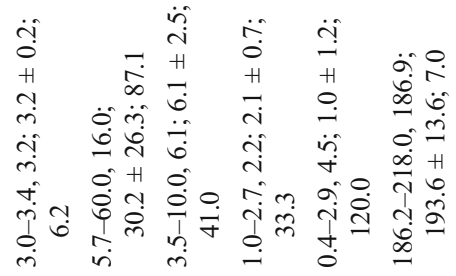

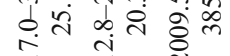

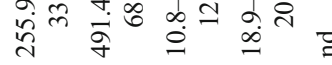

$\begin{array}{ll}\ddot{n} & 0 \\ \dot{0} & \stackrel{\sim}{\sim}\end{array}$

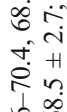

b.

穴事

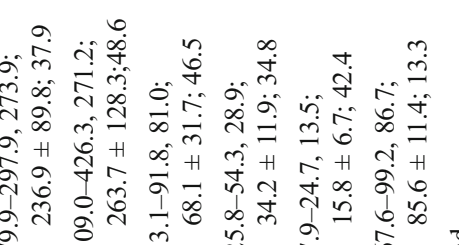

$\ddot{\because} \ddot{\check{I}} \ddot{0} \ddot{0} \quad \ddot{0}$

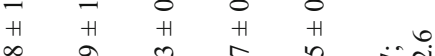

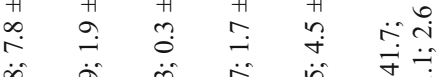

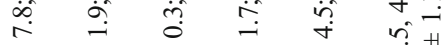
oำ

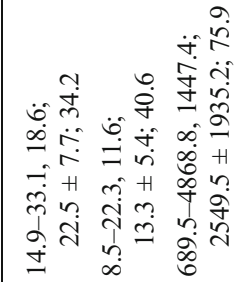

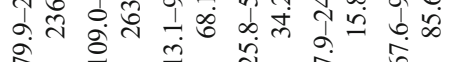

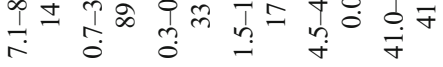


71.4 to $124.4 \mathrm{mg} \mathrm{L}^{-1}$. The obtained results of total flavonoid content are on similar level, as reported in the literature [16-21]. For example, the antioxidant potential of herbs collected in Brazilian Amazonian region was found between 4.2 and $43.8 \mathrm{mg} \mathrm{L}^{-1}$, and also for these plant materials, this value was strongly dependent on the botanical species of the herb [16]. During another study, it was found in extracts of a plant growing in Serbia, Marrubium peregrinum, that total flavonoid concentration was within the range $18.7-54.8 \mathrm{mg} \mathrm{g}^{-1}$ [21]. Our results fall in a similar range. The antioxidant activity ranged from 29.4 to $217.8 \mathrm{mg}$ of Trolox equivalent (TE) per liter and it depended on plant species.

The content of rutin extended from 7.9 in E. herba to $933.4 \mathrm{mg} \mathrm{L}^{-1}$ in $S$. flos. The mean concentration of this flavonoid was equal to $330.5 \mathrm{mg} \mathrm{L}^{-1}$ of infusion. The highest mean level of rutin was noticed in the infusion obtained from S. flos, whereas the lowest was found in E. herba. The lowest level of myricetin was determined in $H$. herba, $66.1 \mathrm{mg} \mathrm{L}^{-1}$, and the highest in $E$. herba, $99.2 \mathrm{mg} \mathrm{L}^{-1}$. The mean concentration of myricetin in all analyzed infusions was $72.7 \mathrm{mg} \mathrm{L}^{-1}$. The contents of quercetin ranged from 61.3 in $H$. herba to $88.3 \mathrm{mg} \mathrm{L}^{-1}$ in $C$. flos, and the mean concentration of this flavonoid was $64.5 \mathrm{mg} \mathrm{L}^{-1}$ in all studied infusions. The content of kaempferol fell in a rather narrow range of concentrations, from $58.1 \mathrm{mg} \mathrm{L}^{-1}$ in $S$. flos to $58.2 \mathrm{mg} \mathrm{L}^{-1}$ in $H$. inforescentia. By comparison of our results with the literature data, it can be stated that they are compatible with those reported in the literature [16-21].

With the results of phenolic acids assays, which fell in the range of concentration of several milligrams per liter, it is possible to distinguish some characteristic plant samples. For example, high concentration of gallic acid was found in one sample of E. herba - $9.7 \mathrm{mg} \mathrm{L}^{-1}$ —and in two of P. herba7.1 and $8.6 \mathrm{mg} \mathrm{L}^{-1}$. Quite high levels of chlorogenic, $p$ coumaric, and caffeic acids, above $10.0 \mathrm{mg} \mathrm{L}^{-1}$, were determined in E. herba, Crataegi folium et flos, and in S. flos. On the other hand, the highest concentration of ferulic acid was found in C. flos-above $173.0 \mathrm{mg} \mathrm{L}^{-1}$. As it was reported earlier, phenolic acids in herbal infusions of lemon balm covered concentration range from 0.001 to $1.589 \mathrm{mg} \mathrm{g}^{-1}$ of dry weight [4]. It can be concluded that the level of phenolic acids determined in the studied samples of medicinal plants is on a similar level, as reported by other researchers [16-21].

\section{Factors Influencing the Differences Between the Studied Plant Samples}

In order to identify statistically significant differences in concentrations of the analytes, ANOVA was used. Especially important was to learn whether or not these differences were due to the fact that analyzed samples originated from different plant species (genetic factor) or from distant areas of growth (geographical aspect).
Taking into consideration the differences due to the origin of samples, only in the case of two metallic elements, Fe and $\mathrm{Zn}$, they were statistically significant between the samples collected in Serbia and those from Portugal. This was confirmed by the results of a post hoc test of LSD (least significant difference), for which the $p$ values were lower than 0.05 . However, for the other analytes, the influence of the growth area was not statistically significant.

On the other hand, the results of ANOVA confirmed the statistically significant differences in the level of 13 analytes arising from the fact of origin of studied herbal samples from different botanical species. The most frequent differences occurred between the level of $\mathrm{Mn}$ and total flavonoid contents. The reason for this differentiation is the genetic factor, which also confirms earlier findings in relation to analysis of elements in medicinal plant families [23].

\section{Relationships Among Essential Elements and the Phenolic Compounds}

The results of correlation analysis are shown in Table 4 . Statistically significant correlations $(\alpha<0.05)$ were found between the pairs: total $\mathrm{P}$ and phosphate $\mathrm{P}, \mathrm{Zn}-\mathrm{Mn}, \mathrm{Mn}-\mathrm{Cu}$, and total flavonoids-antioxidant activity. The relationship of antioxidant activity vs total flavonoid content is presented in Fig. 1, and it can be noted the characteristic group of samples from one plant species-Hypericum perforatum. Several statistically significant relations were also found among phenolic acids and other analytes, for instance, between metallic elements ( $\mathrm{Zn}, \mathrm{Mn}$ and $\mathrm{Cu}$ ), and $p$-coumaric acid. High correlations were found for caffeic acid-quercetin $(r=0.98)$ and for ferulic acid-quercetin $(r=0.81)$ pairs.

In the case of essential elements, their interrelations are affected by participation in biochemical metabolic pathways of medicinal plants. Also, positive relation between total flavonoids and antioxidant activity of the infusions of medicinal plants can be explained by chemical properties of these compounds. A characteristic finding is the high correlation between the total $\mathrm{P}$ and its water-extractable inorganic phosphate $\mathrm{P}$ form, which confirms our earlier results $[13,14]$.

\section{The Essential Elements and the Human Health}

Based on the values of the Dietary Reference Intakes (DRIs), it is possible to calculate the contributions of $\mathrm{P}, \mathrm{Fe}, \mathrm{Zn}, \mathrm{Mn}$, and $\mathrm{Cu}$ water-extractable forms to the human diet [24]. Assuming that the consumers at the age interval of 5170 years drink daily two cups of herbal tea (infusion), the amounts of the studied elements were related to the DRIs, as shown in Table 5.

Inspection of these data has shown that the highest contribution of all investigated essential elements was that of $\mathrm{Mn}$, especially for the infusions obtained from $H$. herba and 
Table 4 The results of correlation analysis

\begin{tabular}{|c|c|c|c|c|c|c|c|c|c|c|}
\hline & $\sum \mathrm{Fl}$ & Rutin & Myricetin & Quercetin & $\mathrm{Fe}$ & $\mathrm{Mn}$ & $\mathrm{Zn}$ & $\mathrm{Cu}$ & $P$ & $\mathrm{CA}$ \\
\hline Myricetin & -0.29 & -0.62 & 1 & & & & & & & \\
\hline Quercetin & -0.57 & 0.11 & 0.27 & 1 & & & & & & \\
\hline Kaempferol & 0.62 & -0.53 & 0.02 & 0.41 & & & & & & \\
\hline $\mathrm{Fe}$ & -0.30 & 0.05 & 0.07 & 0.60 & 1 & & & & & \\
\hline $\mathrm{Mn}$ & 0.73 & 0.23 & -0.42 & -0.39 & -0.38 & 1 & & & & \\
\hline $\mathrm{Zn}$ & 0.29 & 0.46 & -0.27 & -0.23 & -0.33 & 0.57 & 1 & & & \\
\hline $\mathrm{Cu}$ & -0.33 & -0.50 & 0.62 & 0.26 & -0.18 & -0.59 & -0.35 & 1 & & \\
\hline $\mathrm{P}$ & -0.07 & 0.59 & -0.19 & -0.01 & -0.09 & -0.08 & 0.06 & -0.30 & 1 & \\
\hline $\mathrm{P}-\mathrm{PO}_{4}$ & 0.11 & 0.58 & -0.26 & -0.29 & -0.17 & 0.09 & 0.14 & -0.40 & 0.91 & \\
\hline AOX & 0.73 & 0.07 & -0.29 & -0.12 & -0.27 & 0.68 & 0.12 & -0.36 & -0.19 & \\
\hline GA & -0.45 & -0.12 & 0.21 & -0.34 & 0.27 & -0.40 & -0.26 & 0.42 & -0.17 & \\
\hline CGA & 0.05 & 0.05 & -0.11 & -0.01 & -0.01 & -0.11 & 0.01 & -0.11 & 0.27 & \\
\hline $\mathrm{CA}$ & -0.16 & 0.11 & 0.04 & 0.98 & 0.24 & -0.12 & -0.02 & -0.01 & 0.23 & 1 \\
\hline$p \mathrm{CA}$ & -0.22 & -0.07 & 0.09 & -0.38 & 0.19 & -0.57 & -0.38 & 0.64 & -0.05 & -0.20 \\
\hline FA & -0.34 & 0.50 & -0.05 & 0.81 & 0.18 & -0.22 & -0.12 & -0.10 & 0.54 & 0.66 \\
\hline
\end{tabular}

The statistically significant $(\alpha<0.05)$ correlation coefficients are printed in italic

$\sum \mathrm{Fl}$ total contents of flavonoids, $A O X$ antioxidant activity, $P-P_{4}$ phosphate phosphorus, $G A$ gallic acid, $C G A$ chlorogenic acid, $C A$ caffeic acid, $p C A p$ coumaric acid, $F A$ ferulic acid

H. inforescentia. Also, the infusions prepared from P. herba deliver high, as compared with the remaining herbal infusions, quantities of Fe. These data are in general agreement with the results of previous studies on contributions of $\mathrm{Fe}, \mathrm{Mn}, \mathrm{Cu}$, and $\mathrm{Zn}$ in an infusion obtained from one of the Amazonian plants used in medicine, especially in the case of water-extractable forms of $\mathrm{Mn}$ and $\mathrm{Zn}$ [25].

\section{Cluster and Principal Component Analyses}

The results of CA shown in Fig. 2 allow to distinguish five wellseparated clusters grouping the samples with similar properties. Cluster I, which is well separated from the other three clusters, includes almost all samples of $E$. herba, whereas cluster II comprises samples of $P$. herba and $C$. flos. Next, cluster III can be
Fig. 1 Correlation between the antioxidant activity and total flavonoids content for the medicinal herbs from various European regions

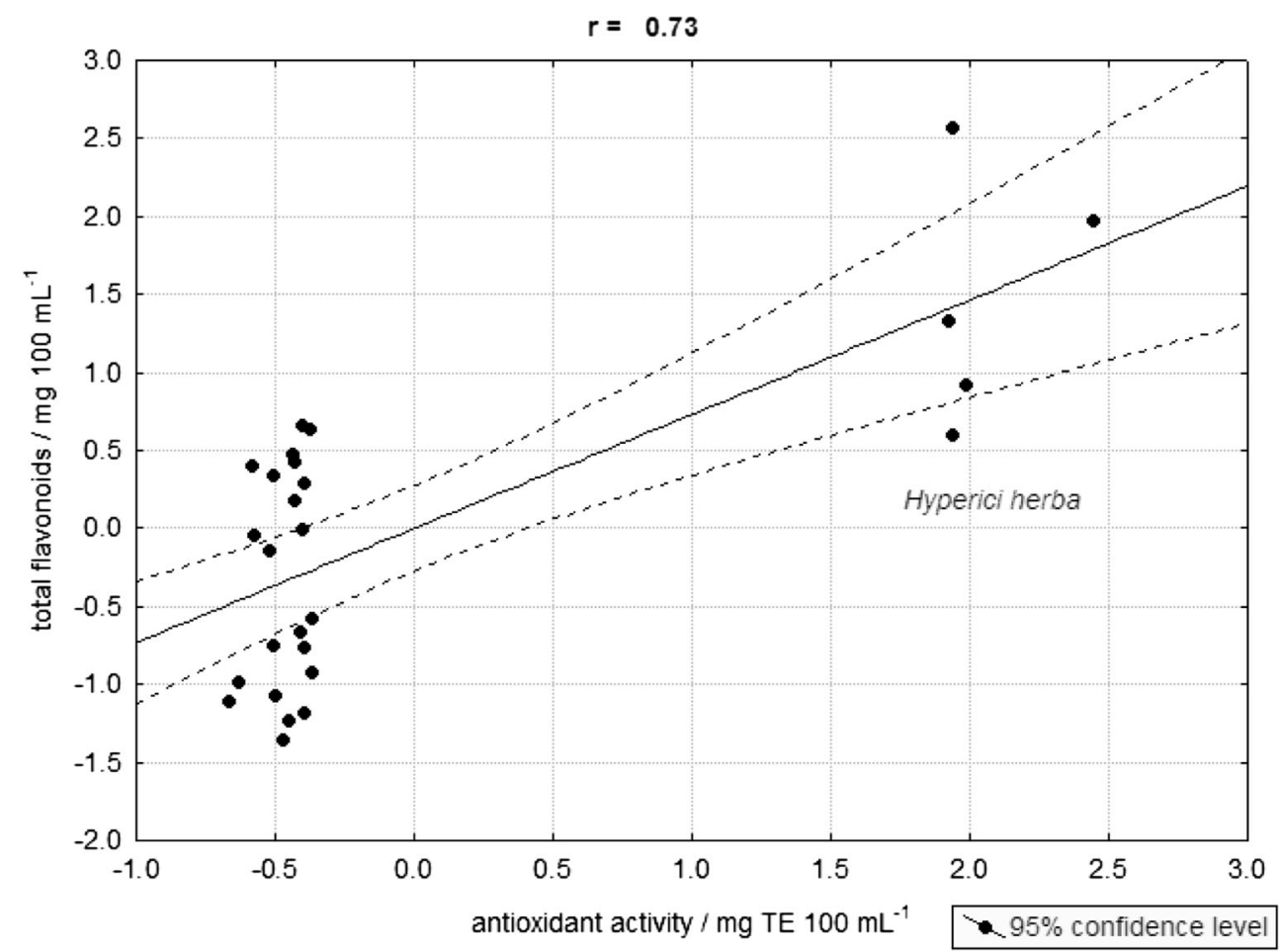


Table 5 Contributions of essential elements in herbal infusions to the Dietary Reference Intakes (DRIs) values

\begin{tabular}{|c|c|c|c|c|c|c|c|}
\hline \multirow[t]{3}{*}{ Infusion of herbal remedy } & \multicolumn{7}{|c|}{ Contribution of essential element to DRI (\%) } \\
\hline & \multirow{2}{*}{$\begin{array}{l}\mathrm{P} \\
\mathrm{M}=\mathrm{W}\end{array}$} & \multirow{2}{*}{$\begin{array}{l}\mathrm{Fe} \\
\mathrm{M}=\mathrm{W}\end{array}$} & \multicolumn{2}{|l|}{$\mathrm{Zn}$} & \multicolumn{2}{|l|}{$\mathrm{Mn}$} & \multirow{2}{*}{$\begin{array}{l}\mathrm{Cu} \\
\mathrm{M}=\mathrm{W}\end{array}$} \\
\hline & & & M & $\mathrm{W}$ & M & $\mathrm{W}$ & \\
\hline Equiseti herba & 1.3 & 9.0 & 1.2 & 1.7 & 5.9 & 7.5 & 4.5 \\
\hline Polygoni herba & 1.8 & 24.1 & 1.5 & 2.0 & 14.9 & 19.1 & 0.7 \\
\hline Hyperici herba & 2.1 & 5.2 & 1.7 & 2.3 & 26.3 & 33.7 & 0.8 \\
\hline Crataegi folium et flos & 2.1 & 10.9 & 1.6 & 2.2 & 16.1 & 20.6 & 1.1 \\
\hline Sambuci flos & 4.2 & 11.9 & 1.5 & 2.1 & 13.2 & 16.9 & 1.2 \\
\hline Chamomillae flos & 3.9 & 12.1 & 1.5 & 2.0 & 11.9 & 15.2 & 1.5 \\
\hline Helichrysi inflorescentia & 2.0 & 6.9 & 2.8 & 3.8 & 27.3 & 34.8 & 1.8 \\
\hline Mean value & 2.5 & 11.4 & 1.7 & 2.3 & 16.5 & 21.1 & 1.7 \\
\hline
\end{tabular}

DRIs for $P=700 \mathrm{mg} /$ day (men and women); $\mathrm{Fe}=8 \mathrm{mg} /$ day (men and women); $\mathrm{Zn}=11 \mathrm{mg} /$ day, $\mathrm{men}=8 \mathrm{mg} /$ day (women); $\mathrm{Mn}=2.3 \mathrm{mg} /$ day (men), $1.8 \mathrm{mg} /$ day (women); $\mathrm{Cu}=0.9 \mathrm{mg} /$ day (men and women). Values for both sexes at age interval $51-70$ years

$M$ men, $W$ women

identified as the one with the samples of $S$. flos. The cluster IV contains all samples of $H$. herba, and cluster V comprises the samples from $C$. folium et flos and $H$. inflorescentia.

Preliminary calculations of PCA has shown that when the experimental database comprise all studied parameters (5 phenolic acids, 4 flavonoids, total flavonoids, antioxidant activity, contents of essential elements), the results are not satisfactory because the two first principal components (PCs) explain together less than $50 \%$ of variability among the samples. However, when the starting database contains only 12 parameters, the two first PCs explain together almost $56 \%$ of variability.
Therefore, after calculation of PCA, the twodimensional PC1 vs PC2 scatterplot of the studied samples of medicinal plant infusions (Fig. 3) reveals their characteristic distribution. As it can be noticed, there are five clearly distinguished groups of plant materials. In the left hand part of the plot, there is a group of samples belonging to E. herba and $P$. herba and in the right hand upper corner, one can notice a group including $H$. herba. In the central area, there are samples of $C$. folium et flos. Two samples of $H$. inflorescentia are located in the right hand part of the plot.
Fig. 2 Results of cluster analysis for the medicinal herb samples

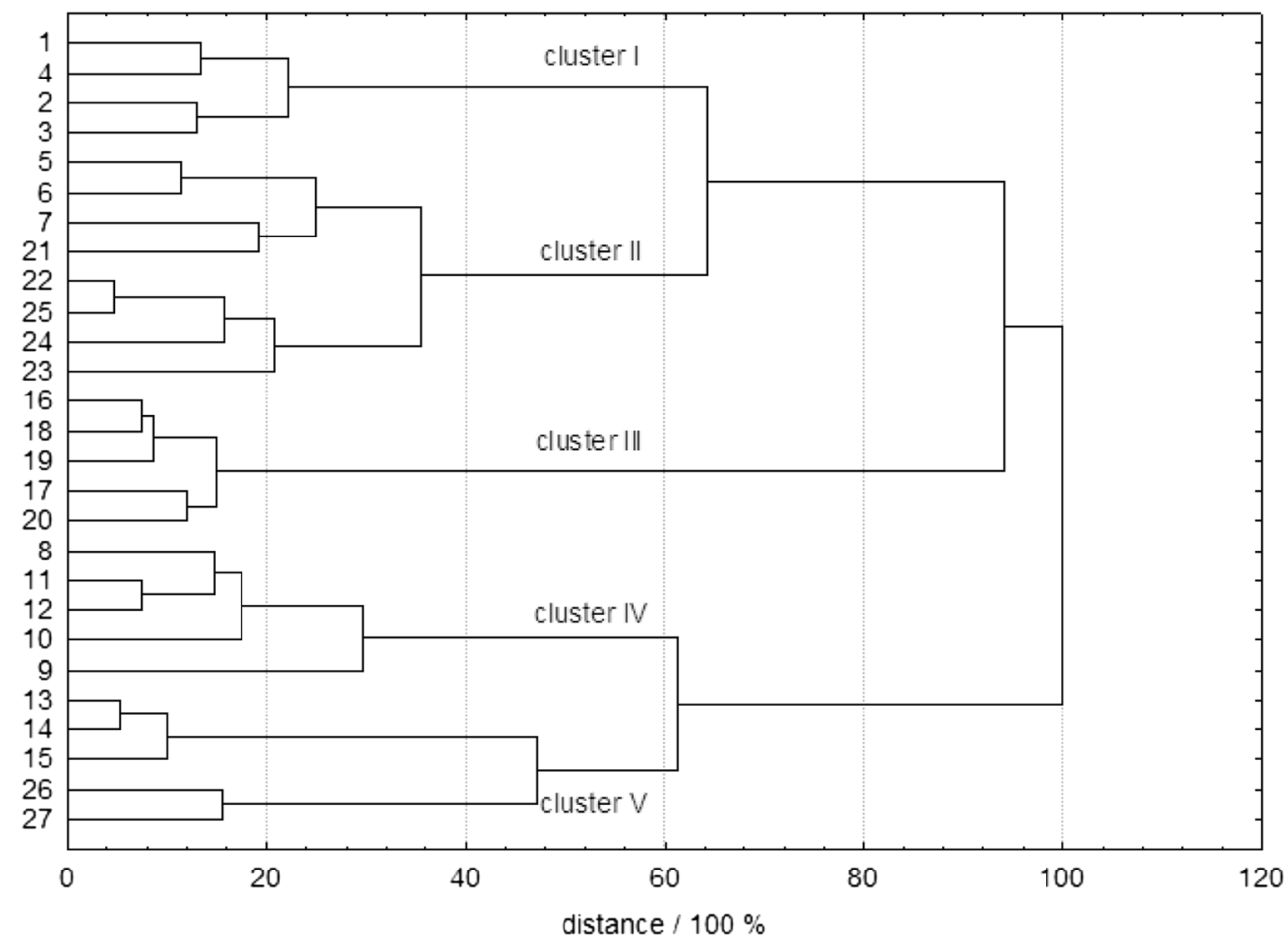


Fig. 3 PCA scatterplot of first two principal components obtained for the European medicinal herbs

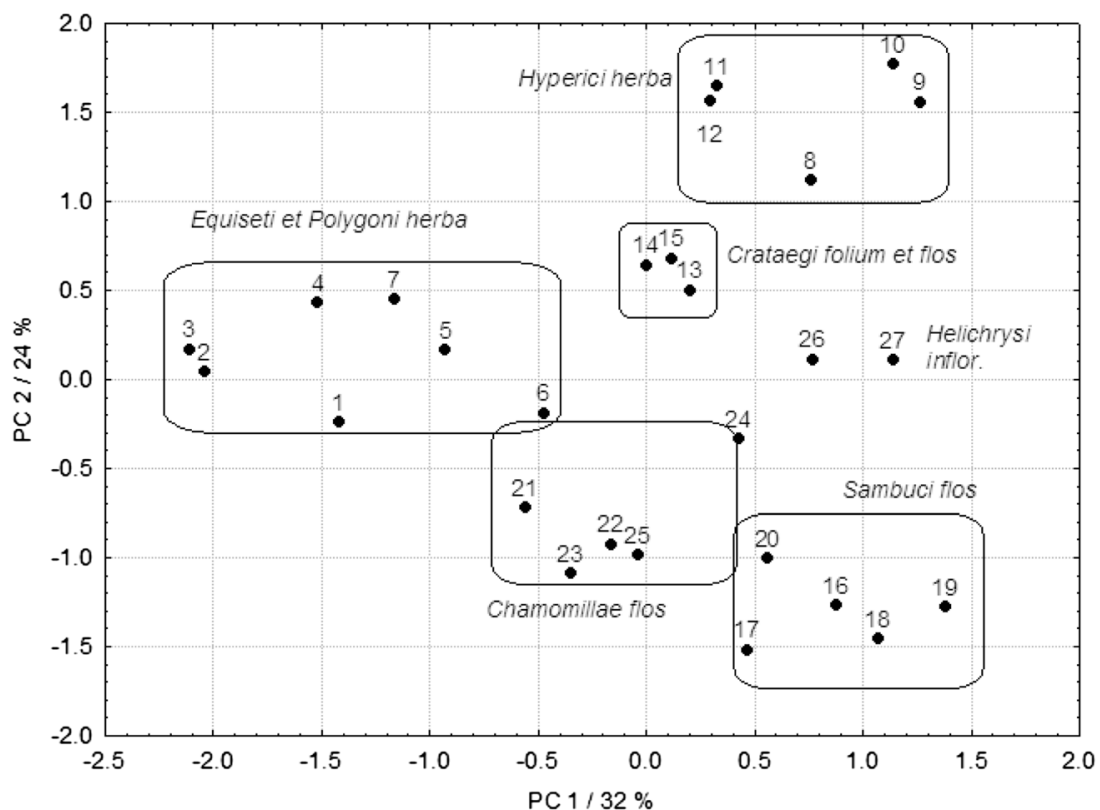

In the lower part of the plot there are two groups of samples. The first one includes C. flos, and in the right hand down corner, there is a second group with the samples of S. flos. Thus, it can be stated that the results of PCA are compatible with those obtained by CA. Owing to application of CA and PCA, a massive impact of botanical species of a medicinal plant (genetic factor) could be revealed on classification of the samples. The fact that the studied plants originated from distant geographical areas of Europe was not statistically significant. Moreover, PCA enabled to select the concentrations of essential elements, such as $\mathrm{Mn}$ and $\mathrm{Cu}$, also the total $\mathrm{P}$ and water-extractable phosphate $\mathrm{P}$, as the factors which strongly influence the differentiation of the studied medicinal plant materials (Fig. 4).

\section{Conclusions}

Based on the study of medicinal plant infusions, the studied plant samples can be characterized by specific phenolic compounds and antioxidant activity along with the contents of selected essential elements. The main conclusion is that plants belonging to different botanical species differ significantly in their chemical composition, as it could be demonstrated by the ANOVA. In general, with the exception of a significant difference in $\mathrm{Fe}$ and $\mathrm{Zn}$ levels between the samples from Portugal and Serbia, the plant materials do not exhibit statistically significant differences associated with the origin from distant areas of Europe. Moreover, the use of CA and PCA
Fig. 4 Loading plot for PCA results obtained for the medicinal herbs from different European regions

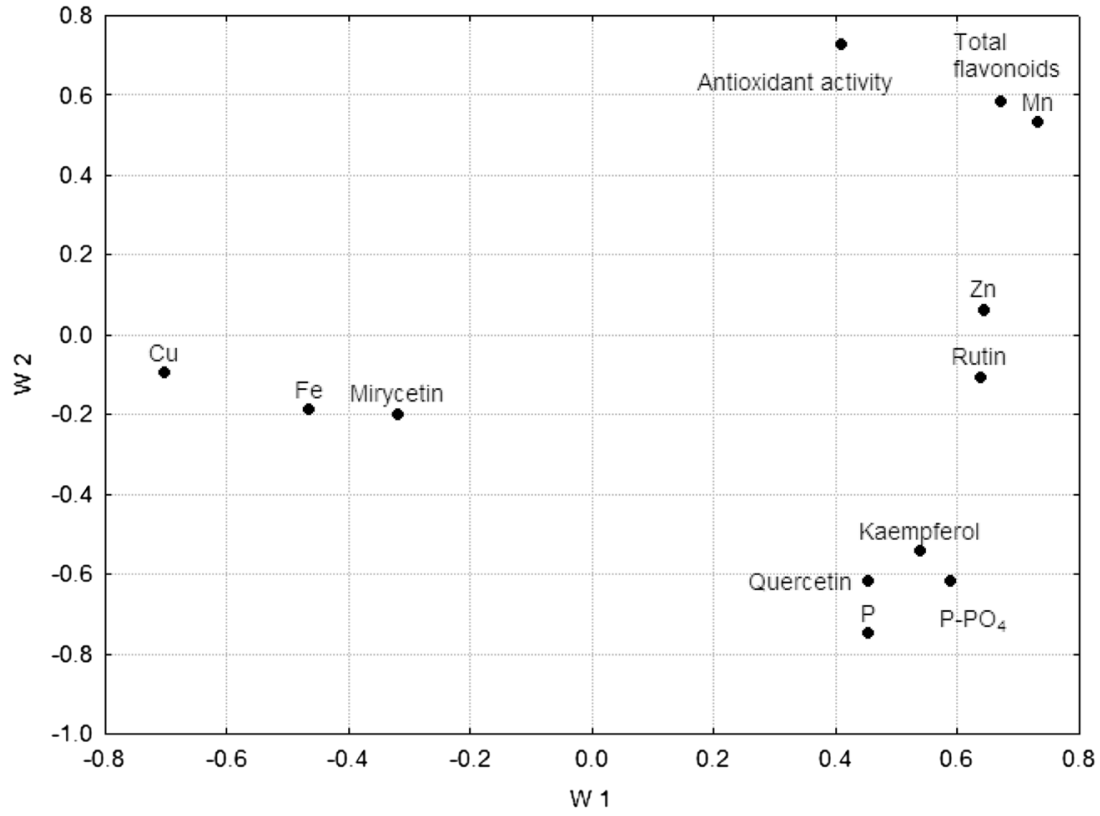


confirmed the massive impact of botanical species of a medicinal plant (genetic factor) on classification of the samples. The analysis of contributions of essential elements to the DRIs indicates that high concentrations of water-extractable forms of $\mathrm{Mn}$ and $\mathrm{Fe}$ are found in infusions obtained from H. herba and $H$. inforescentia.

Acknowledgments This project was supported by the Ministry of Science and Higher Education of the Republic of Poland, from the qualitypromoting subsidy, under the Leading National Research Centre (KNOW) program for the years 2012-2017.

The authors wish to thank for kind delivery of the herbal medicinal products for the study, especially Vida Vickackaite (Lithuania), Filip Miljkovic (Serbia), Joanna Herczynska-Ballan (Italy), and Joaquim Morgado and Tiago Faifa from the company Ervital (Portugal).

Conflict of interest The authors declare that they have no competing interests.

Open Access This article is distributed under the terms of the Creative Commons Attribution 4.0 International License (http:// creativecommons.org/licenses/by/4.0/), which permits unrestricted use, distribution, and reproduction in any medium, provided you give appropriate credit to the original author(s) and the source, provide a link to the Creative Commons license, and indicate if changes were made.

\section{References}

1. Haq I (2004) Safety of medicinal plants. Pakistan J Med Res 43:1-8

2. Wright CI, Van-Buren L, Kroner CI, Koning MMG (2007) Herbal medicines as diuretics: a review of the scientific evidence. J Ethnopharm 114:1-31

3. Farag MA, Wessjohann LA (2012) Metabolome classification of commercial Hypericum perforatum (St. John's wort) preparations via UPLC-qTOF-MS and chemometrics. Planta Med 78:488-496

4. Arceusz A, Wesolowski M (2013) Quality consistency evaluation of Melissa officinalis L. commercial herbs by HPLC fingerprint and quantitation of selected phenolic acids. J Pharm Biomed Anal 83: 215-220

5. Yang J, Chen LH, Zhang Q, Lai MX, Wang Q (2007) Quality assessment of Cortex cinnamoni by HPLC chemical fingerprint, principle component analysis and cluster analysis. J Sep Sci 30: 1276-1283

6. Tian R, Xie P, Liu H (2009) Evaluation of traditional Chinese herbal medicine: chaichu (Bupleuri radix) by both high-performance liquid chromatographic and high-performance thin-layer chromatographic fingerprint and chemometric analysis. J Chrom A 1216: 2150-2155

7. Kunlu OF, Egharevba HO, Ahmadu PO (2012) Standardization of herbal medicines - a review. Int J Biodivers Conserv 4:101-112

8. Garg V, Dhar VJ, Sharma A, Dutt R (2012) Facts about standardization of herbal medicine: a review. Chin J Integr Med 10:10771083

9. Moreira HS, Vasconcellos MBA, Alves ER, Santos FM, Saiki M (2011) Elemental composition of herbal medicines sold over-the- counter in Sao Paulo City, Brazil. J Radioanal Nucl Chem 290:615621

10. Arumugam R, Kannan RRR, Jayalakshmi J, Manivannan K, Devi GK, Anantharaman P (2012) Determination of element contents in herbal drugs: chemometric approach. Food Chem 135:2372-2377

11. Pytlakowska K, Kita A, Janoska P, Polowniak M, Kozik V (2012) Multi-element analysis of mineral and trace elements in medicinal herbs and their infusions. Food Chem 135:494-501

12. Karadas C, Kara D (2012) Chemometric approach to evaluate trace metal concentrations in some spices and herbs. Food Chem 130: 196-202

13. Konieczynski P, Wesolowski M (2007) Determination of zinc, iron, nitrogen and phosphorus in several botanical species of medicinal plants. Polish J Environ Stud 16:785-790

14. Konieczynski P, Wesolowski M, Radecka I, Rafalski P (2011) Bioavialable inorganic forms of essential elements in medicinal plants from Northern Poland. Chem Spec Bioavial 23:61-70

15. Basgel S, Erdemoglu SB (2006) Determination of mineral and trace elements in some medicinal herbs and their infusions consumed in Turkey. Sci Total Environ 359:82-89

16. da Silva P's P, Chiste RC, Godoy HT, Prado MA (2013) The phenolic compounds and the antioxidant potential of infusion of herbs from the Brazilian Amazonian region. Food Res Int 53:875-881

17. Riehle P, Vollmer M, Rohn S (2013) Phenolic compounds in Cistus incanus herbal infusions - antioxidant capacity and thermal stability during the brewing process. Food Res Int 53:891-899

18. Rohman A, Riyanto S, Yuniarti N, Saputra WR, Utami R, Mulatsih W (2010) Antioxidant activity, total phenolic, and total flavonoid of extracts and fractions of red fruit (Pandanus conoideus Lam). Int Food Res J 17:97-106

19. Ferreira Zielinski A, Haminiuk CWI, Alberti A, Nogueira A, Demiate IM, Granato D (2014) A comparative study of the phenolic compounds and the in vitro antioxidant activity of different Brazilian teas using multivariate statistical techniques. Food Res Int 60:246-254

20. Dillenburg Meinhart A, Shaper Bizotto C, Ballus CA, Poloni Rybka AC, Sobrinho MR, Cerro-Quintana RS, Texeira-Filho J, Texeira Godoy H (2010) Methylxanthines and phenolic content extracted during the consumption of mate (Ilex paraguariensis $\mathrm{St}$. Hil) beverages. J Agric Food Chem 58:2188-2193

21. Stankovic MS (2011) Total phenolic content, flavonoid concentration and antioxidant activity of Marrubium peregrinum L. extracts. Kragujevac J. Sci. 33:63-72

22. Otto M (1999) Chemometrics. Analysis of variance, pattern recognition and classification. In: Otto M (ed) Statistics and computer application in analytical chemistry, vol 41-49. Wiley-VCH, Weinheim, pp. 119-173

23. Arceusz A, Radecka I, Wesolowski M (2010) Identification of diversity in elements contents in medicinal plants belonging to different plant families. Food Chem 120:52-58

24. National Academy of Sciences (2004) Dietary Reference Intakes (DRIs): recommended intakes for individuals, Elements. Available from http://www.nap.edu

25. Dos Santos Magalhaes IR, de Oliveira Soares A, Araujo LM, Castro da Costa PR, de Araujo RI, Lozano Borras MR (2009) Determination of $\mathrm{Cu}, \mathrm{Fe}, \mathrm{Mn}$, and $\mathrm{Zn}$ in the leaves and tea of Arrabidaea chica (Humb. \& Bompl.) Biol Trace Elem Res 132: 239-246 